Article

\title{
Genetic Sequence Variants in TLR4, MBL or $I L-1$ Receptor Antagonist is not Associated to Increased Risk for Febrile Neutropenia in Children with ALL
}

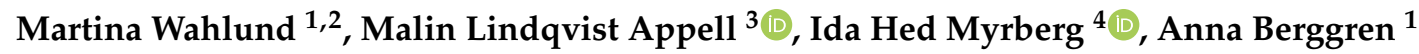 \\ and Anna Nilsson 4,5,*(D) \\ 1 Department of Medicine Solna, Division of Infectious Diseases, Karolinska Institutet, \\ 17164 Stockholm, Sweden; martina.wahlund@ki.se (M.W.); anna.berggren@ki.se (A.B.) \\ 2 Department of Clinical Microbiology, Karolinska University Hospital, 17164 Stockholm, Sweden \\ 3 Department of Medical and Health Sciences, Division of Drug Research, Linkoping University, \\ 58183 Linkoping, Sweden; malin.lindqvist.appell@liu.se \\ 4 Childhood Cancer Research Unit, Department of Women's and Children's Health, Karolinska Institutet, \\ 17165 Stockholm, Sweden; ida.hed.myrberg@ki.se \\ 5 Astrid Lindgren Children's Hospital, Karolinska University Hospital, 17164 Stockholm, Sweden \\ * Correspondence: anna.nilsson.1@ki.se; Tel.: +46-707-500139
}

Received: 17 November 2020; Accepted: 10 December 2020; Published: 16 December 2020

\begin{abstract}
Sequence variants in genes involved in the immune system have previously been linked to neutropenia as well as infections in cancer patients. Sequence variants in genes coding for TLR4, MBL, and $I L-1 R a$ were investigated in relation to clinical utility of identifying severe episodes of febrile neutropenia (FN) in a cohort of children undergoing treatment for acute lymphoblastic leukemia. The study included 122 children, where data on FN and microbiological findings were retrospectively collected from medical records. Sequence variants in genes coding for MBL, TLR4, and IL-1Ra were identified by pyrosequencing, TaqMan SNP genotyping assay, and gel electrophoresis. A total of 380 episodes of FN were identified and in 139 episodes, there was a microbiological defined infection. Age and treatment intensity were all associated with the risk of developing FN. No sequence variant was associated to increased numbers of FN episodes. Two sequence variants in the TLR4 gene increased the risk of viral infection, whilst sequence variants in the IL-1Ra gene were associated to a decreased risk of bacterial blood-stream infection (BSI). The investigated sequence variants did not associate with increased risk for FN or to severe infections, as to why the clinical utility as a risk-stratification tool is low. Most episodes of FN were classified as fever with unknown origin, emphasizing the need for improved microbial detection methods.
\end{abstract}

Keywords: febrile neutropenia; acute lymphoblastic leukemia; TLR4; $M B L ; I L-1 R a$

\section{Introduction}

Acute lymphoblastic leukemia (ALL) is the most frequent cancer in children. The long-term survival of children with ALL has increased considerably [1], although complications associated with chemotherapy are common. Still, infections remain as a cause of increased morbidity and mortality [2,3]. Data on febrile neutropenia (FN) and microbiological defined infections (MDI) during the entire pediatric ALL treatment period is limited. Recent studies have reported that bacterial bloodstream infections (BSI) and invasive fungal disease (IFD) still account for most infection-related deaths. Viral infections, mainly respiratory infections, are also commonly detected in FN [3-6]. Thus, early identification of children at risk of severe infections during chemotherapy could be a way forward and lead to improved antibiotic treatment strategies for a subgroup of children with ALL. 
The great variability in the frequency and severity of infections in children with ALL implies an individualized susceptibility to infection. Previous studies have associated sequence variants in genes coding for the innate immune proteins Toll-like receptor 4 (TLR4), mannose-binding lectin (MBL), and interleukin-1 receptor antagonist $(I L-1 R a)$ to increased risk for either bacterial or viral infection during cancer therapy [7-12]. Sequence variants in the TLR4 have been associated with an increased risk of sepsis, Gram-negative BSI, as well as the development of chemotherapy-induced neutropenia [11-13]. Data regarding sequence variants in the $M B L$ and risk of FN in children during chemotherapy are inconclusive, with studies indicating an increased risk of bacterial infection, whilst some studies do not suggest any correlation to FN or any other MDI [9-11,14,15]. The IL1RN*2 allele has been associated with an increase in the susceptibility to sepsis and clinically severe sepsis in adults, but also to an increased risk of septic shock in children with ALL [7,16,17].

Previous studies lack stringency in patient cohorts where data for children with different cancers are compared as well as where patients on different treatment protocols are compared for these gene sequence variants. In addition, definitions of etiology of FN have been lacking. Therefore, the primary aim of the current study was to assess the clinical utility of these gene sequence variants in risk stratification of FN in a homogenous cohort of pediatric ALL patients.

\section{Materials and Methods}

\subsection{Study Cohort}

Children diagnosed with ALL between May 2004 and April 2014 at Astrid Lindgren Children's Hospital (Stockholm, Sweden), and subsequently treated within the Nordic Society for Pediatric Hematology and Oncology (NOPHO) ALL 2000 and 2008 protocols, were retrospectively included in the study. The NOPHO ALL registry was used for patient identification. The following exclusion criteria were used: (i) Resistant disease leading to change of treatment protocol, (ii) previous chemotherapy treatment, (iii) infant-ALL, (iv) Philadelphia chromosome-positive ALL, (v) germ-line chromosomal abnormalities, (vi) known immunodeficiencies, (vii) missing sample, or (viii) insufficient treatment information in the medical records. The study was conducted in accordance with the Declaration of Helsinki, and the protocol was approved by the the Regional Ethical Review Board in Stockholm, Sweden (Dnr: 2016/442-31/2).

There were some differences in treatment intensity between the 2000 and 2008 protocol; children treated within the standard (SR) and intermediate risk (IR) groups in the 2008 protocol received slightly higher doses of chemotherapy. In the 2008 protocol, patients in the IR group received an extra delayed consolidation before the start of maintenance II. In addition, the subsequent maintenance II was supplemented with intrathecal methotrexate (MTX) at 8-week intervals. However, the main difference was that the high-risk (HR) groups received significantly more intensive chemotherapy with at least six high-dose chemotherapy blocks in the 2008 protocol as compared to the 2000 protocol.

\subsection{Data Collection}

Children were followed from the diagnosis of ALL to the end of treatment (2.5 years), until hematopoietic stem-cell transplantation (HSCT), or to relapse within the primary treatment protocol. FN was defined as two or more spikes at least one hour apart of a temperature $\geq 38.0^{\circ} \mathrm{C}$ or a single spike $\geq 38.5^{\circ} \mathrm{C}$, with a neutrophil count of $\leq 1 \times 10^{9}$ cells/L at the time of the fever or decreasing to $\leq 0.5 \times 10^{9}$ cells/L within $48 \mathrm{~h}$ of fever onset [18]. Patient characteristics, numbers of FN episodes, microbiological findings (bacterial BSI, IFD, or viral infections) during the episodes of FN were retrospectively collected from patient charts.

Due to the retrospective approach of the study, all microbiological findings were controlled by two clinicians (AN, MW) using predefined criteria to decide whether the microbiological findings were relevant or not. Bacterial BSI with a positive blood culture were included if there was an intention-to-treat at the time of infection. Pathogens defined as contaminants by the laboratory and 
the clinician at the time of infection were excluded. For respiratory viral infections, the samples were analyzed using either viral isolation or immunofluorescence (until 30 September 2007) and thereafter, PCR on nasopharyngeal aspirates (NPA) [19]. Positive NPA samples were included only if they occurred simultaneously with respiratory symptoms. For gastrointestinal viral infections, children with repeated positivity were excluded due to the prolonged viral shedding of these viruses [20,21]. IFD was included only if there was a positive microbial finding in an otherwise sterile compartment corresponding to the European Organization for Research and Treatment of Cancer/Mycoses Study Group (EORTC/MSG) criteria of proven IFD [22].

\subsection{Gene Sequence Variant Analysis}

In short, targeted sequences and the ILIRN sequence repeat were amplified in a total volume of $10 \mu \mathrm{L}$ using $1 \mathrm{ng}$ DNA, $1 \times$ QIAGEN HotStarTaq Master Mix, with $2 \mathrm{mM} \mathrm{MgCl} 2$ and $0.4 \mu \mathrm{M}$ individual PCR-primers and primers originally from Tarlow et al. for IL1RN (supporting information; Tables S1 and S2) [23]. The following PCR amplification conditions were used: $15 \mathrm{~min}$ at $95{ }^{\circ} \mathrm{C}$; 45 cycles of $15 \mathrm{~s}$ at $95^{\circ} \mathrm{C}, 90 \mathrm{~s}$ at $55^{\circ} \mathrm{C}$, and $30 \mathrm{~s}$ at $72{ }^{\circ} \mathrm{C} ; 10 \mathrm{~min}$ at $72{ }^{\circ} \mathrm{C}$.

Genotyping was performed using pyrosequencing (supporting information; Tables S1 and S2) to test for MBL rs1800450, rs5030737, rs1800451 and TLR4 rs2737190, rs1927911, rs10759931, and rs11536889 as according to the manufacturer's instructions as earlier described in Wahlund et al., 2019 [24]. For two sequence variants in TLR4, genotyping was performed using TaqMan ${ }^{\mathrm{TM}}$ (Applied Biosystems, Foster City, CA, USA) SNP Genotyping Assay detecting rs4986790 (assay IDC11722238) and rs4986791 (assay IDC11722237). In short, 5 ng DNA was mixed with $2 \times$ TaqMan $^{\mathrm{TM}}$ Genotyping Master Mix Cat\#4371355, $0.25 \mu \mathrm{l}$ of $20 \times$ genotyping assay, in a total volume of $10 \mu \mathrm{l}$. The thermocycling and data analysis were performed with an ABI 7500 Real-Time PCR instrument (Applied Biosystems, Foster City, CA, USA) using standard mode. For IL1RN, the resulting product after PCR was detected by agarose gel electrophoresis (E Gel ${ }^{\mathrm{TM}}$ General Purpose Agarose Gels, 2\%, Invitrogen, Carlsbad, CA, USA) to determine the size(s) of amplicon(s) corresponding to a variable number of repeats. A fragment of $410 \mathrm{bp}$ corresponded to four repeats of the $86 \mathrm{bp}$ sequence (IL1RN*1), $240 \mathrm{bp}$ fragment to two repeats $\left(I L 1 R N^{*} 2\right)$, and $500 \mathrm{bp}$ to five repeats (IL1RN*3) [23].

\subsection{Statistical Analysis}

Descriptive statistics are presented as medians, inter-quartile range, and range for continuous variables, and frequencies and percentages for categorical variables. The association between covariates and time to FN and the different MDI, respectively, was evaluated using Andersen-Gill models, i.e., semi-parametric survival models allowing for recurring events, taking into account that one child may have had multiple episodes [25]. The function coxph in the R package survival was used to fit the models [26,27]. Episodes where more than one type of infection was detected (e.g., co-infection with bacteria and virus), were excluded from the final analysis. Censoring was made for end of treatment (typically 130 weeks after diagnosis), relapse, death, or HSCT.

First, the association between time to FN/MDI and the background variables age at diagnosis (years), phenotype (T-cell/pre-B ALL), risk group (SR/IR/HR), and protocol (NOPHO-ALL 2000/NOPHO-ALL 2008) were evaluated in univariable Andersen-Gill models. The linearity assumption of the age covariate was tested by comparing a model with a restricted 3-knot cubic spline basis for age to a model with a linear assumption for age, using a Wald test. For FN, bacterial BSI, and Gram-negative BSI, the linearity assumption did not hold, and age was adjusted for using restricted cubic splines. The association between sequence variants and time to FN/MDI was then evaluated in univariable models, and adjusted for statistically significant background variables in multivariable models. Adjustments for age, risk group, and protocol were made for FN, bacterial BSI, and Gram-negative BSI. Gram-positive BSI was adjusted for age and risk group and viral infections were adjusted for age and protocol. The proportional hazards assumption was checked by testing the correlation between the scaled Schoenfeld residuals and rank-ordered event times. $R$ version 3.6.0 was used for all analyses [28]. 


\section{Results}

\subsection{Patient Characteristics and Episodes of FN}

Of the 157 identified children, 122 met the inclusion criteria (Table 1). The median age was 5.4 years (range 1.1-17.9), and 54, 48, and 20 children were treated within the SR, IR, and HR groups, respectively. Eight patients suffered from relapse within the treatment period (median time to relapse 80.9 weeks, range 35.9-120.6 weeks), two were transferred to HSCT, and two died within the follow up due to infectious-related complications.

Table 1. Patient characteristics of the 122 included children treated for ALL.

\begin{tabular}{|c|c|}
\hline Characteristics & $n(\%)$ \\
\hline \multicolumn{2}{|l|}{ Gender } \\
\hline Female & $58(47.5)$ \\
\hline Male & $64(52.4)$ \\
\hline \multicolumn{2}{|l|}{ Risk Group } \\
\hline Standard risk & $54(44.3)$ \\
\hline Intermediate risk & $48(39.3)$ \\
\hline High risk & $20(16.4)$ \\
\hline \multicolumn{2}{|l|}{ Protocol } \\
\hline NOPHO ALL-2000 & $43(35.2)$ \\
\hline NOPHO ALL-2008 & $79(64.8)$ \\
\hline \multicolumn{2}{|l|}{ Phenotype of ALL } \\
\hline Pre-B ALL & $106(86.9)$ \\
\hline T-cell ALL & $16(13.1)$ \\
\hline \multicolumn{2}{|l|}{ Outcome } \\
\hline Relapse * & $8(6.6)$ \\
\hline HSCT & $2(1.6)$ \\
\hline Death during follow up & $2(1.6)$ \\
\hline & Median (range; IQR) \\
\hline Age at diagnosis (years) & $5.4(1.1-17.9 ; 3.3-10.4)$ \\
\hline
\end{tabular}

* within 2.5 years from diagnosis. Abbreviations: ALL, Acute lymphoblastic leukemia; HSCT, Hematopoietic stem-cell transplantation; IQR, interquartile range.

A total of $380 \mathrm{FN}$ episodes were documented within the cohort of 122 children corresponding to a median of three episodes (range 0-11, interquartile range IQR 1-4) in each child. From the clinical diagnostic procedures, viral infection was identified in $64(16.8 \%)$ of the FN episodes (median 0 , range $0-5$ episodes), bacterial BSI in 61 (16.1\%) episodes (median 0 , range $0-5$ episodes), only IFD in two (0.5\%) episodes, and twelve (3.2\%) episodes were mixed infections (Figure 1A). In the majority of FN episodes $(n=240)$, no microbiologic pathogen was identified and these episodes were classified as fever of unknown origin (FOU). Bacterial BSI was more commonly detected during the first months of ALL treatment, but in HR-ALL also during the first year when intense therapy is administered. On the other hand, viral infections were present during the entire treatment period, especially in the SR- and IR-groups (Figure 1B,C). 


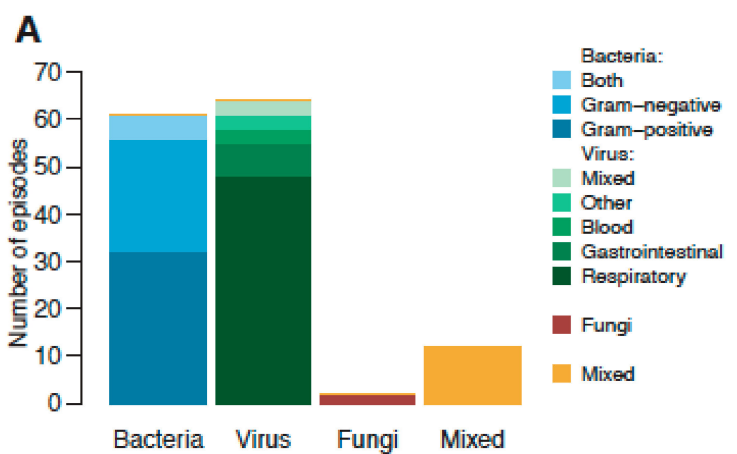

B

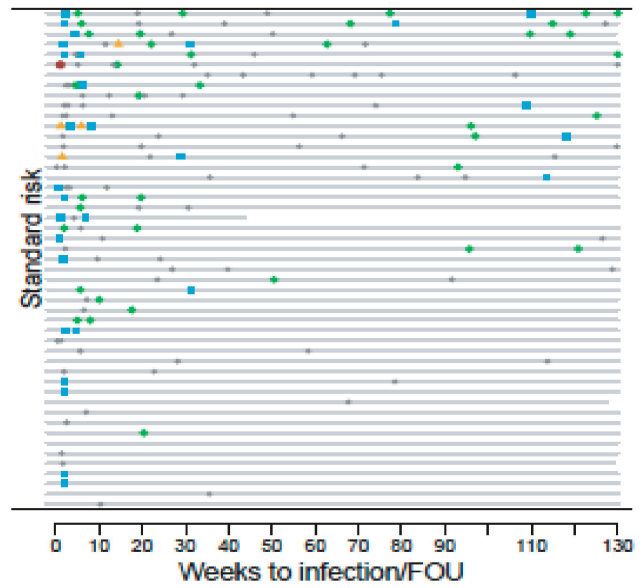

C

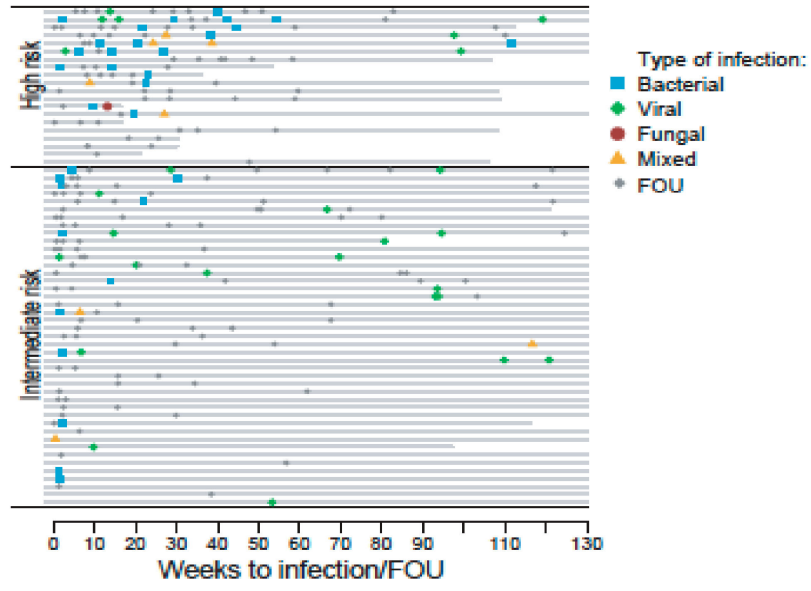

Figure 1. FOU and MDI during episodes of FN during the entire ALL treatment. (A) MDI ( $n=139)$ within the 380 episodes of FN. Nine of the bacterial BSI and viral infections were co-infections with both virus and bacteria, six of the bacterial BSI were both Gram-positive and Gram-negative, and for the IFD, four were mixed infections where one combined with virus, two combined with bacterial BSI, and one combined with both virus and bacterial BSI. (B,C) Occurrence of FN episodes during the entire ALL treatment sorted after respective MDI or fever of unknown origin (FUO) and treatment intensity standard (SR), intermediate (IR) and high risk (HR). Each line represents one patient. The HR groups in the 2000 protocol were only treated for 104 weeks.

Thereafter, the overall risk of FN, as well as the risk for the respective MDI, were analyzed. Age at diagnosis was an identified risk factor of developing FN and the respective MDI, however, the association between age and the natural logarithm of the hazard function was not linear (Figure 2A). Younger age was more associated to an increased risk for viral infections and Gram-positive BSI, whilst Gram-negative BSI was associated to an increased risk in both the younger and older ages (Figure 2B-E). In addition, treatment intensity (the NOPHO ALL 2008 treatment protocol as well as treatment for the HR-groups) were associated with more episodes of FN. 
A

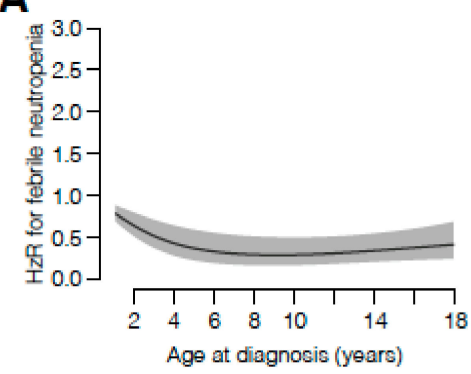

D

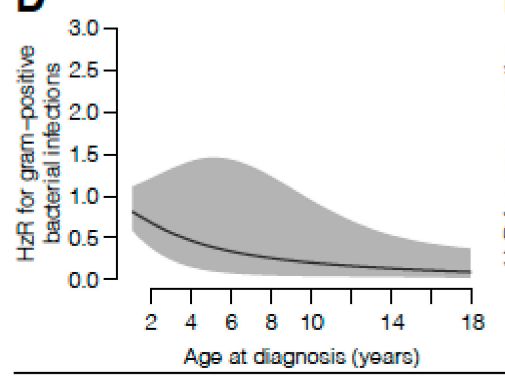

B

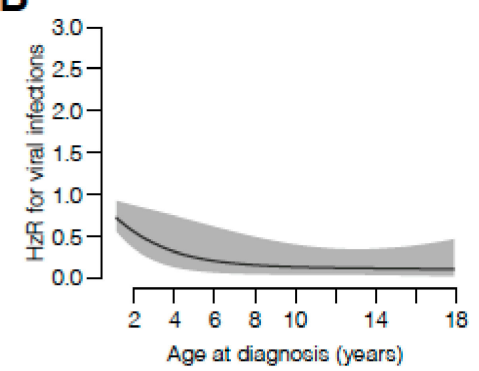

E

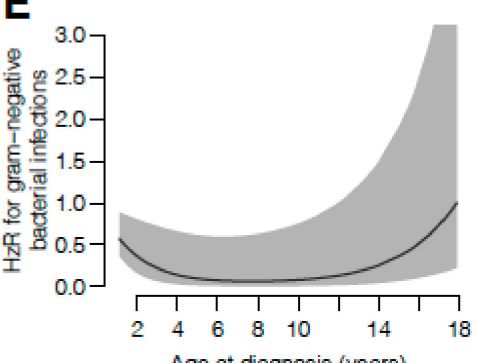

C

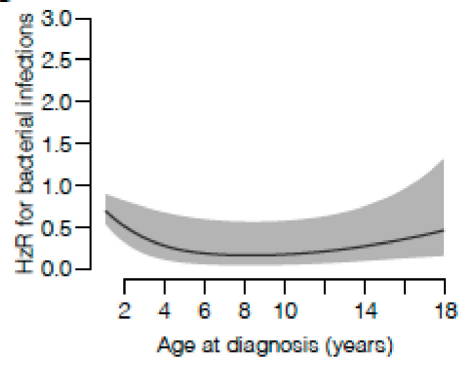

Figure 2. (A-E): Age impact on the risk of FN and respective MDI. Hazard ratio (HzR) for a one-year increase in age at diagnosis, calculated using 3-knot restricted cubic splines for age in Andersen-Gill models, for (A) febrile neutropenia, (B) viral infections, (C) bacterial BSI, (D) Gram-positive BSI, (E) Gram-negative BSI.

\subsection{Genetic Sequence Variants and the Overall Risk of FN and MDI}

Thereafter, we performed genotyping, which was successful for the vast majority of the samples (except for two samples, one for the Rs4986790 and one for IL1RN). At least one of the different sequence variants investigated were identified in 117 (TLR4), 39 (MBL2), and 55 (IL1RN) children (supporting information, Tables S3 and S4), thus some children harbored more than one sequence variant, both within the same gene and in between the genes investigated.

The analysis of microbiological findings in relation to sequence variants was stringently performed where only bacterial BSI episodes ( $n=61$, viral and IFD excluded) or only viral episodes $(n=64$, bacterial and IFD excluded) were taken into account, respectively. Thereafter, a sub-analysis of episodes with Gram-positive or Gram-negative bacteria was performed (co-presence of Gram-positive and Gram-negative bacteria were excluded).

When comparing the different sequence variants to all the episodes of FN (Table 2), as well as to the respective MDIs, two sequence variants in TLR4; rs10759931 and rs11536889 were associated with an increased risk of viral infections. For sequence variants in the ILI Ra gene, children with at least one sequence variant (heterozygous or homozygous) in both the IL1RN*2 allele and IL1RN*3 allele were grouped together and thereafter identified to have a decreased risk of bacterial BSI as compared to wild-type children. In addition, further analysis of the bacterial infections (either Gram-positive $(n=32)$ or Gram-negative BSI $(n=24))$ showed that the IL1RN*2 allele was associated with a decreased risk of Gram-negative BSI (unadjusted: HzR; 0.29, CI; 0.10-0.85; $p$-value; 0.025, adjusted: HzR; 0.31, CI; $0.11-0.88 ; p$-value; 0.029 ). The same analysis for the IL1RN 3 allele and Gram-positive BSI could not be performed since none of these children had any episodes of Gram-positive BSI. 
Table 2. Association between sequence variants in genes coding for TLR4, MBL, and IL-1Ra and the risk of FN and specific MDI during pediatric ALL treatment.

\begin{tabular}{|c|c|c|c|c|c|c|}
\hline \multirow[b]{2}{*}{$\begin{array}{l}\text { Sequence } \\
\text { Variant }\end{array}$} & \multicolumn{2}{|c|}{$\begin{array}{l}\text { Febrile Neutropenia } \\
\qquad(n=380)\end{array}$} & \multicolumn{2}{|c|}{ Bacterial BSI $(n=61)$} & \multicolumn{2}{|c|}{ Viral Infection $(n=64)$} \\
\hline & Unadjusted & Adjusted & Unadjusted & Adjusted & Unadjusted & Adjusted \\
\hline $\begin{array}{c}\text { TLR4 } \\
\text { rs } 2737190\end{array}$ & $\begin{array}{l}1.03(0.78- \\
1.35 ; 0.83)\end{array}$ & $\begin{array}{l}1.01(0.82- \\
1.24 ; 0.93)\end{array}$ & $\begin{array}{l}1.02(0.59- \\
1.75 ; 0.94)\end{array}$ & $\begin{array}{l}0.93(0.59- \\
1.46 ; 0.74)\end{array}$ & $\begin{array}{l}0.88(0.48- \\
1.62 ; 0.69)\end{array}$ & $\begin{array}{l}0.96(0.56- \\
1.66 ; 0.89)\end{array}$ \\
\hline TLR4 & $0.93(0.71-$ & $0.96(0.78-$ & $0.98(0.57-$ & $0.97(0.61-$ & $0.70(0.39-$ & $0.74(0.43-$ \\
\hline rs1927911 & $1.21 ; 0.6)$ & $1.18 ; 0.69)$ & $1.70 ; 0.95)$ & $1.55 ; 0.90)$ & $1.27 ; 0.24)$ & $1.26 ; 0.27)$ \\
\hline TLR4 & $0.93(0.71-$ & $0.94(0.77-$ & $0.89(0.50-$ & $0.88(0.56-$ & $2.46(1.17-$ & $2.38(1.24-$ \\
\hline rs10759931 & $1.23 ; 0.62)$ & $1.15 ; 0.55)$ & $1.61 ; 0.71)$ & $1.41 ; 0.60)$ & $5.18 ; 0.017)$ & $4.57 ; 0.0094)$ \\
\hline TLR4 & $0.96(0.72-$ & $1.09(0.86-$ & $0.82(0.46-$ & $1.02(0.59-$ & $1.59(0.86-$ & $1.94(1.14-$ \\
\hline rs11536889 & $1.28 ; 0.79)$ & $1.39 ; 0.45)$ & $1.45 ; 0.49)$ & $1.76 ; 0.94)$ & $2.96 ; 0.14)$ & $3.31 ; 0.015)$ \\
\hline TLR4 & $1.04(0.63-$ & $1.04(0.73-$ & $1.25(0.52-$ & $1.23(0.63-$ & $0.80(0.28-$ & $0.92(0.35-$ \\
\hline rs4986790 & $1.72 ; 0.87)$ & $1.48 ; 0.84)$ & $2.99 ; 0.62)$ & $2.39 ; 0.54)$ & $2.27 ; 0.68)$ & $2.39 ; 0.87)$ \\
\hline $\begin{array}{c}\text { TLR4 } \\
\text { rs4986791 } \\
\text { TLR4 }\end{array}$ & $\begin{array}{l}0.94(0.61- \\
1.45 ; 0.79)\end{array}$ & $\begin{array}{l}0.90(0.66- \\
1.22 ; 0.48)\end{array}$ & $\begin{array}{l}0.93(0.42- \\
2.04 ; 0.85)\end{array}$ & $\begin{array}{l}0.80(0.44- \\
1.47 ; 0.48)\end{array}$ & $\begin{array}{c}0.73(0.29- \\
1.85 ; 0.5)\end{array}$ & $\begin{array}{l}0.74(0.31- \\
1.75 ; 0.49)\end{array}$ \\
\hline $\begin{array}{l}\text { rs4986790 } \\
\text { and } \\
\text { rs4986791 } \\
M B L\end{array}$ & $\begin{array}{l}0.96(0.64- \\
1.45 ; 0.86)\end{array}$ & $\begin{array}{l}0.94(0.70- \\
1.27 ; 0.68)\end{array}$ & $\begin{array}{l}1.18(0.57- \\
2.45 ; 0.66)\end{array}$ & $\begin{array}{l}1.06(0.58- \\
1.91 ; 0.85)\end{array}$ & $\begin{array}{l}0.69(0.27- \\
1.76 ; 0.43)\end{array}$ & $\begin{array}{l}0.71(0.30- \\
1.70 ; 0.44)\end{array}$ \\
\hline $\begin{array}{l}\text { rs1800450, } \\
\text { rs5030737 } \\
\text { and } \\
\text { rs1800451 }\end{array}$ & $\begin{array}{l}1.09(0.83- \\
1.43 ; 0.53)\end{array}$ & $\begin{array}{l}1.09(0.89- \\
1.35 ; 0.41)\end{array}$ & $\begin{array}{l}0.70(0.37- \\
1.32 ; 0.27)\end{array}$ & $\begin{array}{l}0.78(0.44- \\
1.38 ; 0.39)\end{array}$ & $\begin{array}{l}0.78(0.37- \\
1.67 ; 0.53)\end{array}$ & $\begin{array}{l}0.79(0.40- \\
1.58 ; 0.51)\end{array}$ \\
\hline$I L 1 R N^{*} 2$ & $\begin{array}{l}1.08(0.83- \\
1.41 ; 0.55)\end{array}$ & $\begin{array}{l}1.07(0.86- \\
1.34 ; 0.52)\end{array}$ & $\begin{array}{c}0.49(0.28- \\
0.88 ; 0.016)\end{array}$ & $\begin{array}{c}0.51(0.31- \\
0.84 ; 0.009)\end{array}$ & $\begin{array}{l}1.65(0.88- \\
3.10 ; 0.12)\end{array}$ & $\begin{array}{l}1.47(0.84- \\
2.58 ; 0.17)\end{array}$ \\
\hline $\operatorname{IL1RN} N^{*} 3$ & $\begin{array}{l}1.24(0.58- \\
2.68 ; 0.58)\end{array}$ & $\begin{array}{l}0.87(0.58- \\
1.30 ; 0.49)\end{array}$ & $\begin{array}{l}0.25(0.04- \\
1.54 ; 0.14)\end{array}$ & $\begin{array}{c}0.16(0.05- \\
0.51 ; 0.0022)\end{array}$ & $\begin{array}{l}1.72(0.62- \\
4.74 ; 0.3)\end{array}$ & $\begin{array}{l}1.09(0.47- \\
2.54 ; 0.85)\end{array}$ \\
\hline
\end{tabular}

Results are presented as $\mathrm{HzR}$ (CI; and $p$-value); Adjusted; for age, protocol, and risk group for FN and bacterial BSI and only for age and protocol for viral infection. All infectious episodes were analyzed as only bacterial BSI (viral and IFD excluded) and only viral infections (bacterial and IFD excluded). Significant gene sequence variants for the respective MDI in bold.

\section{Discussion}

Treatment-related infections are still a major concern during ALL treatment as it negatively affects morbidity and mortality. Risk-stratification could improve management of FN in the immunosuppressed child and previous studies have indicated a role for TLR4, MBL, and IL-IRa sequence variants as risk factors for serious infections in immunocompromised children. Contrary to previous findings, the present study demonstrates that two specific sequence variants in the TLR4 increased the risk of viral associated FN, whilst a sequence variant in the IL-1Ra gene decreased the risk of bacterial BSI. Sequence variants in $M B L$ did not affect FN or any of the MDI.

Several previous studies have reported that viral (mainly respiratory) infections are the most commonly verified infection (44-50\%) during FN [6,29-33]. The lower proportion of viral infections in this study could be explained by different methods used for viral detection during the study period and that viral sampling was less stringent compared to blood culture sampling. Bacterial BSI were reported in $16.1 \%$ of the FN in the present study, which is in concordance with other studies $[29,30,34]$. Notably, in the current study, only $~ 40 \%$ of the FN had a proven etiology, which is a limitation of our study. However, it also highlights the importance of improved methods for microbial detection in children with ALL as suggested by us previously [35].

Next, we investigated whether genetic sequence variants in the innate immune proteins alter the risk of FN and associated MDI and thus, could be implemented as a risk-stratification tool. A previous study reported that TLR4 sequence variants (rs10759931, rs11536889, rs6478317, and rs1927911) 
increased the risk of neutropenia in children treated for ALL [13]. Herein, we show that both the rs10759931 and rs11536889 increase the risk of viral infections during FN, but not to the number of episodes of FN in general. Since earlier studies mainly have associated TLR4 sequence variants to the increased risk of Gram-negative bacterial infections, these findings were rather surprising $[11,12,36,37]$. Albeit, Awomoyi et al. reported that TLR4 sequence variants (rs4986790 and rs4986791) were associated with symptomatic RSV infection in otherwise healthy infants [38].

Sequence variants in the gene coding for $I L-1 R a$ have been investigated mainly in adult cohorts. To our knowledge, only one study has investigated the $I L-1 R a$ in children treated for ALL, showing that children heterozygous or homozygous for the IL1RN*2 had an increased risk of developing septic shock [7]. On the contrary, the present study identified a decreased risk of bacterial BSI in children with $I L 1 R N^{*} 2$ and $I L 1 R N^{*} 3$ alleles. However, the definition of bacterial BSI and septic shock is not identical, hampering the comparisons of these two studies. Previous studies investigating $M B L$ deficiency in children with cancer have reported contradictory results [8-11,14,15,39], whilst we could not show any association between $M B L$ sequence variants and FN during the treatment for childhood ALL. Consequently, the present study strengthens the evidence that MBL does not play a role during episodes of FN and associated MDI.

Despite our findings, one outstanding issue when investigating the role of gene sequence variants is the limited knowledge of how these findings correspond to phenotype and protein levels in vivo $[16,40,41]$. For $I L-1 R a$, it is not yet known whether high or low levels of the protein would increase or decrease the risk of bacterial BSI and sepsis. The development of sepsis occurs due to the pathogens itself and to an excessive inflammatory response by the immune system. Therefore, are high or low levels of $I L-1 R a$ favorable or not in terms of sepsis development? Unfortunately, this could not be addressed by us as no plasma proteins were measured simultaneously. Another possible confounder is the redundancy in the immune system where previous studies have shown that the IL-1Ra gene not only affects the production of $I L-1 R a$, but also the $I L-1 \alpha$ levels, and that the gene coding for $I L-1 \beta$ also may affect the $I L-1 R a$ production $[40,41]$. The clinical utility of assessing gene variants in innate immune molecules is also hampered by many different outcome measurements in studies concerning children with ALL. When searching the literature to identify additional gene variants to include in this study, we identified two studies, investigating TLR9 and lymphotoxin-alpha respectively, but with induction mortality as primary focus $[42,43]$. This was not possible in our cohort since we lacked induction deaths.

To summarize, the investigated gene sequence variants did not associate to increased risk for repeated episodes of FN, nor to increased risk for bacterial etiology as to why the clinical utility as a risk stratification tool is low. Most episodes of FN were however classified as fever of unknown origin which also may affect the clinical usefulness of these sequence variants for risk stratification. Our study also shows the need for stringent sampling and improved microbial detection methods in immunosuppressed children with FN to properly assess causality between etiology and fever.

Supplementary Materials: The following are available online at http://www.mdpi.com/2227-9067/7/12/296/s1, Table S1: Pyrosequencing PCR-primers and primers for detection of sequence variants in the genes coding for $T L R 4, M B L$ and $I L-1 R a$ (intron 2). Table S2: Sequencing primers and settings for pyrosequencing reactions. Table S3: Genotyping results MBL and TLR4. Table S4: Genotyping results IL-1Ra gene (IL1RN).

Author Contributions: A.N., A.B. and M.L.A. designed the study. M.W. and A.B. included all patients. M.W., M.L.A., I.H.M. generated the data. M.W., M.L.A., I.H.M., A.B. and A.N. analyzed and organized the data. M.W. and A.N. wrote the manuscript. All authors have read and agreed to the published version of the manuscript.

Funding: This work was supported by grants from the Swedish Childhood Cancer Foundation and the Swedish Society of Medicine.

Conflicts of Interest: The authors have no conflict of interests. The grant providers had no influence on study design, the collection, analyses and interpretation of data, report writing nor decision of submission for publication. 


\section{References}

1. Schmiegelow, K.; Forestier, E.; Hellebostad, M.; Heyman, M.; Kristinsson, J.; Soderhall, S.; Taskinen, M. Long-term results of NOPHO ALL-92 and ALL-2000 studies of childhood acute lymphoblastic leukemia. Leukemia 2010, 24, 345-354. [CrossRef] [PubMed]

2. Sandeberg, M.A.; Johansson, E.; Wettergren, L.; Björk, O.; Hertting, O.; Nilsson, A. Antibiotic use during infectious episodes in the first 6 months of anticancer treatment-A Swedish cohort study of children aged 7-16 years. Pediatr. Blood Cancer 2017, 64, e26397. [CrossRef] [PubMed]

3. Lund, B.; Åsberg, A.; Heyman, M.; Kanerva, J.; Harila-Saari, A.; Hasle, H.; Söderhäll, S.; Jónsson, Ó.G.; Lydersen, S.; Schmiegelow, K.; et al. Risk factors for treatment related mortality in childhood acute lymphoblastic leukaemia. Pediatr. Blood Cancer 2010, 56, 551-559. [CrossRef] [PubMed]

4. Inaba, H.; Pei, D.; Wolf, J.; Howard, S.C.; Hayden, R.T.; Go, M.; Varechtchouk, O.; Hahn, T.; Buaboonnam, J.; Metzger, M.L.; et al. Infection-related complications during treatment for childhood acute lymphoblastic leukemia. Ann. Oncol. 2017, 28, 386-392. [CrossRef] [PubMed]

5. Li, M.-J.; Chang, H.-H.; Yang, Y.-L.; Lu, M.-Y.; Shao, P.-L.; Fu, C.-M.; Chou, A.-K.; Liu, Y.-L.; Lin, K.-H.; Huang, L.-M.; et al. Infectious complications in children with acute lymphoblastic leukemia treated with the Taiwan Pediatric Oncology Group protocol: A 16-year tertiary single-institution experience. Pediatr. Blood Cancer 2017, 64, e26535. [CrossRef] [PubMed]

6. Söderman, M.; Rhedin, S.; Tolfvenstam, T.; Rotzén-Östlund, M.; Albert, J.; Broliden, K.; Lindblom, A. Frequent Respiratory Viral Infections in Children with Febrile Neutropenia-A Prospective Follow-Up Study. PLoS ONE 2016, 11, e0157398. [CrossRef] [PubMed]

7. Zapata-Tarrés, M.; Arredondo-García, J.L.; Rivera-Luna, R.; Klünder-Klünder, M.; Mancilla-Ramírez, J.; Sánchez-Urbina, R.; Vázquez-Cruz, M.Y.; Juárez-Villegas, L.E.; Palomo-Colli, M.A. Interleukin-1 Receptor Antagonist Gene Polymorphism Increases Susceptibility to Septic Shock in Children With Acute Lymphoblastic Leukemia. Pediatr. Infect. Dis. J. 2013, 32, 136-139. [CrossRef] [PubMed]

8. Neth, O.; Hann, I.; Turner, M.W.; Klein, N.J. Deficiency of mannose-binding lectin and burden of infection in children with malignancy: A prospective study. Lancet 2001, 358, 614-618. [CrossRef]

9. Dommett, R.; Chisholm, J.; Turner, M.; Bajaj-Elliott, M.; Klein, N.J. Mannose-binding Lectin Genotype Influences Frequency and Duration of Infectious Complications in Children With Malignancy. J. Pediatr. Hematol. 2013, 35, 69-75. [CrossRef] [PubMed]

10. Pana, Z.D.; Samarah, F.; Papi, R.; Antachopoulos, C.; Papageorgiou, T.; Farmaki, E.; Hatzipantelis, E.; Tragiannidis, A.; Vavatsi-Christaki, N.; Kyriakidis, D.; et al. Mannose binding lectin and ficolin-2 polymorphisms are associated with increased risk for bacterial infections in children with B acute lymphoblastic leukemia. Pediatr. Blood Cancer 2014, 61, 1017-1022. [CrossRef]

11. Pehlivan, M.; Sahin, H.H.; Ozdilli, K.; Onay, H.; Ozcan, A.; Ozkinay, F.; Pehlivan, S. Gene Polymorphisms and Febrile Neutropenia in Acute Leukemia-No Association with IL-4, CCR-5, IL-1RA, but the MBL-2, ACE, and TLR-4 Are Associated with the Disease in Turkish Patients: A Preliminary Study. Genet. Test. Mol. Biomarkers 2014, 18, 474-481. [CrossRef] [PubMed]

12. Schnetzke, U.; Spies-Weisshart, B.; Yomade, O.; Fischer, M.; Rachow, T.; Schrenk, K.; Gläser, A.; Von Lilienfeld-Toal, M.; Hochhaus, A.; Scholl, S. Polymorphisms of Toll-like receptors (TLR2 and TLR4) are associated with the risk of infectious complications in acute myeloid leukemia. Genes Immun. 2014, 16, 83-88. [CrossRef] [PubMed]

13. Miedema, K.G.E.; Poele, E.M.T.; Tissing, W.J.E.; Postma, D.S.; Koppelman, G.H.; de Pagter, A.P.; Kamps, W.A.; Alizadeh., B.Z.; de Bont, E.S.J.M. Association of polymorphisms in the TLR4 gene with the risk of developing neutropenia in children with leukemia. Leukemia 2011, 25, 995-1000. [CrossRef] [PubMed]

14. Fekete, F.; Fadgyas, B.; Papp, E.; Szilágyi, Á; Prohászka, Z.; Müller, B.; Kovács, G. The role of mannose binding lectin on fever episodes in pediatric oncology patients. Pathol. Oncol. Res. 2015, 22, 139-143. [CrossRef]

15. Lausen, B.F.; Andreassen, B.; Schmiegelow, K.; Madsen, H.O.; Garred, P. Infections during induction therapy of childhood acute lymphoblastic leukemia-No association to mannose? Binding lectin deficiency. Eur. J. Haematol. 2006, 76, 481-487. [CrossRef]

16. Arnalich, F.M.; López-Maderuelo, D.; Codoceo, R.; Lopez, J.; Solis-Garrido, L.M.; Capiscol, C.; Fernandez-Capitán, C.; Madero, R.; Montiel, C. Interleukin-1 receptor antagonist gene polymorphism and mortality in patients with severe sepsis. Clin. Exp. Immunol. 2002, 127, 331-336. [CrossRef] 
17. Fang, X.M.; Schroder, S.; Hoeft, A.; Stuber, F. Comparison of two polymorphisms of the interleukin-1 gene family: Interleukin-1 receptor antagonist polymorphism contributes to susceptibility to severe sepsis. Crit. Care Med. 1999, 27, 1330-1334. [CrossRef]

18. Freifeld, A.G.; Bow, E.J.; Sepkowitz, K.A.; Boeckh, M.J.; Ito, J.I.; Mullen, C.A.; Raad, I.I.; Rolston, K.V.; Young, J.-A.; Wingard, J. Clinical practice guideline for the use of antimicrobial agents in neutropenic patients with cancer: 2010 update by the iInfectious Diseases Society of America. Clin. Infect. Dis. 2011, 52, 56-93. [CrossRef]

19. Tiveljung-Lindell, A.; Rotzén-Östlund, M.; Gupta, S.; Ullstrand, R.; Grillner, L.; Zweygberg-Wirgart, B.; Allander, T. Development and implementation of a molecular diagnostic platform for daily rapid detection of 15 respiratory viruses. J. Med. Virol. 2009, 81, 167-175. [CrossRef]

20. Henke-Gendo, C.; Harste, G.; Juergens-Saathoff, B.; Mattner, F.; Deppe, H.; Heim, A. New Real-Time PCR Detects Prolonged Norovirus Excretion in Highly Immunosuppressed Patients and Children. J. Clin. Microbiol. 2009, 47, 2855-2862. [CrossRef]

21. Ludwig, A.; Adams, O.; Laws, H.-J.; Schroten, H.; Tenenbaum, T. Quantitative detection of norovirus excretion in pediatric patients with cancer and prolonged gastroenteritis and shedding of norovirus. J. Med. Virol. 2008, 80, 1461-1467. [CrossRef] [PubMed]

22. Donnelly, J.P.; Chen, S.C.; Kauffman, C.A.; Steinbach, W.J.; Baddley, J.W.; Verweij, P.E.; Clancy, C.J.; Wingard, J.R.; Lockhart, S.R.; Groll, A.H.; et al. Revision and Update of the Consensus Definitions of Invasive Fungal Disease From the European Organization for Research and Treatment of Cancer and the Mycoses Study Group Education and Research Consortium. Clin. Infect. Dis. 2020, 71, 1367-1376. [CrossRef] [PubMed]

23. Tarlow, J.K.; Blakemore, A.I.F.; Lennard, A.; Solari, R.; Hughes, H.N.; Steinkasserer, A.; Duff, G.W. Polymorphism in human IL-1 receptor antagonist gene intron 2 is caused by variable numbers of an 86-bp tandem repeat. Qual. Life Res. 1993, 91, 403-404. [CrossRef] [PubMed]

24. Wahlund, M.; Nilsson, A.; Kahlin, A.Z.; Broliden, K.; Myrberg, I.H.; Appell, M.L.; Berggren, A. The Role of TPMT, ITPA, and NUDT15 Variants during Mercaptopurine Treatment of Swedish Pediatric Patients with Acute Lymphoblastic Leukemia. J. Pediatr. 2019. [CrossRef] [PubMed]

25. Andersen, P.K.; Gill, R.D. Cox's Regression Model for Counting Processes: A Large Sample Study. Ann. Statist. 1982, 10, 1110-1120. [CrossRef]

26. Therneau, T.M.; Grambsch, P.M. Modeling Survival Data: Extending the Cox Model; Springer: New York, NY, USA, 2000.

27. Therneau, T.M. A Package for Survival Analysis in S. Available online: https://CRAN.R-project.org/package= survival (accessed on 4 February 2020).

28. R Core Team. R: A Language and Environment for Statistical Computing. 2018. Available online: https: //www.r-project.org/ (accessed on 13 February 2012).

29. Lindblom, A.; Bhadri, V.; Söderhäll, S.; Öhrmalm, L.; Wong, M.; Norbeck, O.; Lindau, C.; Rotzén-Östlund, M.; Allander, T.; Catchpoole, D.; et al. Respiratory viruses, a common microbiological finding in neutropenic children with fever. J. Clin. Virol. 2010, 47, 234-237. [CrossRef]

30. Torres, J.P.; De la Maza, V.; Kors, L.; Villarroel, M.; Piemonte, P.; Izquierdo, G.; Salgado, C.; Tordecilla, J.; Contardo, V.; Farfán, M.J.; et al. Respiratory Viral Infections and Coinfections in Children With Cancer, Fever and Neutropenia: Clinical Outcome of Infections Caused by Different Respiratory Viruses. Pediatr. Infect. Dis. J. 2016, 35, 949-954. [CrossRef]

31. Suryadevara, M.; Tabarani, C.M.; Bartholoma, N.; Rosenberg, H.F.; Domachowske, J.B. Nasopharyngeal Detection of Respiratory Viruses in Febrile Neutropenic Children. Clin. Pediatr. 2012, 51, 1164-1167. [CrossRef]

32. Koskenvuo, M.; Möttönen, M.; Rahiala, J.; Saarinen-Pihkala, U.M.; Riikonen, P.; Waris, M.; Ziegler, T.; Uhari, M.; Salmi, T.T.; Ruuskanen, O. Respiratory Viral Infections in Children With Leukemia. Pediatr. Infect. Dis. J. 2008, 27, 974-980. [CrossRef]

33. Aldemir-Kocabaş, B.; Karbuz, A.; Pekpak, E.; Karahan, Z.C.; Dolapçi, I.; Ince, E.; Uysal, Z.; Yavuz, G.; Çiftçi, E.; Ince, E. Effects of respiratory viruses on febrile neutropenia attacks in children. Turk. J. Pediatr. 2017, 59, 511. [CrossRef] 
34. Koskenvuo, M.; Möttönen, M.; Rahiala, J.; Saarinen-Pihkala, U.M.; Riikonen, P.; Waris, M.; Ziegler, T.; Uhari, M.; Ruuskanen, O.; Salmi, T.T. Mixed Bacterial-Viral Infections in Septic Children With Leukemia. Pediatr. Infect. Dis. J. 2007, 26, 1133-1136. [CrossRef] [PubMed]

35. Wahlund, M.; Sinha, I.; Broliden, K.; Saghafian-Hedengren, S.; Nilsson, A.; Berggren, A. The Feasibility of Host Transcriptome Profiling as a Diagnostic Tool for Microbial Etiology in Childhood Cancer Patients with Febrile Neutropenia. Int. J. Mol. Sci. 2020, 21, 5305. [CrossRef] [PubMed]

36. Agnese, D.M.; Calvano, J.E.; Hahm, S.J.; Coyle, S.M.; Corbett, S.A.; Calvano, S.E.; Lowry, S.F. Human Toll-Like Receptor 4 Mutations but Not CD14 Polymorphisms Are Associated with an Increased Risk of Gram-Negative Infections. J. Infect. Dis. 2002, 186, 1522-1525. [CrossRef] [PubMed]

37. Lorenz, E.; Mira, J.P.; Frees, K.L.; Schwartz, D.A. Relevance of Mutations in the TLR4 Receptor in Patients with Gram-Negative Septic Shock. Arch. Intern. Med. 2002, 162, 1028-1032. [CrossRef]

38. Awomoyi, A.A.; Rallabhandi, P.; Pollin, T.I.; Lorenz, E.; Sztein, M.B.; Boukhvalova, M.S.; Hemming, V.G.; Blanco, J.C.G.; Vogel, S.N. Association of TLR4 Polymorphisms with Symptomatic Respiratory Syncytial Virus Infection in High-Risk Infants and Young Children. J. Immunol. 2007, 179, 3171-3177. [CrossRef]

39. Frakking, F.; Van De Wetering, M.; Brouwer, N.; Dolman, K.; Geissler, J.; Lemkes, B.; Caron, H.; Kuijpers, T. The role of mannose-binding lectin (MBL) in paediatric oncology patients with febrile neutropenia. Eur. J. Cancer 2006, 42, 909-916. [CrossRef]

40. Danis, V.A.; Millington, M.; Hyland, V.J.; Grennan, D. Cytokine production by normal human monocytes: Inter-subject variation and relationship to an IL-1 receptor antagonist (IL-1Ra) gene polymorphism. Clin. Exp. Immunol. 1995, 99, 303-310. [CrossRef]

41. Hurme, M.; Santtila, S. IL-1 receptor antagonist (IL-1Ra) plasma levels are co-ordinately regulated by both IL-1Ra and IL-1beta genes. Eur. J. Immunol. 1998, 28, 2598-2602. [CrossRef]

42. Bhadri, V.A.; Beckett, S.M.; Duncan, C.; Marshall, G.M.; Ashton, L.J. Variation in Toll-like receptor 9 gene modifies the risk of infection in children treated for acute lymphoblastic leukemia. Leuk. Lymphoma 2012, 53, 1828-1830. [CrossRef]

43. Kidas, E.; Möricke, A.; Beier, R.; Welte, K.; Schrappe, M.; Stanulla, M.; Grigull, L. Genetic polymorphisms of the lymphotoxin alpha gene are associated with increased risk for lethal infections during induction therapy for childhood acute leukemia: A case-control study. Int. J. Hematol. 2009, 89, 584-591. [CrossRef]

Publisher's Note: MDPI stays neutral with regard to jurisdictional claims in published maps and institutional affiliations.

(C) 2020 by the authors. Licensee MDPI, Basel, Switzerland. This article is an open access article distributed under the terms and conditions of the Creative Commons Attribution (CC BY) license (http://creativecommons.org/licenses/by/4.0/). 